CONSTRUCTION AND GEOLOGIC LOG OF THE SOUTH WAILUA MONITOR WELL (STATE WELL 2-0121-01),

LIHUE, KAUAI, HAWAII

By Scot K. Izuka and Stephen B. Gingerich

U.S. GEOLOGICAL SURVEY

Open-File Report 97-38

Prepared in cooperation with the

COUNTY OF KAUAI DEPARTMENT OF WATER

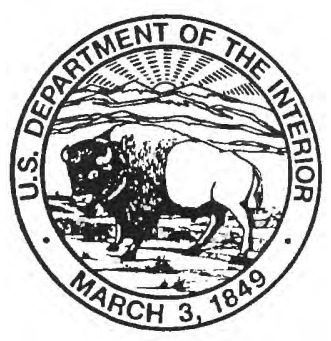




\section{U.S. DEPARTMENT OF THE INTERIOR BRUCE BABBITT, Secretary}

U.S. GEOLOGICAL SURVEY

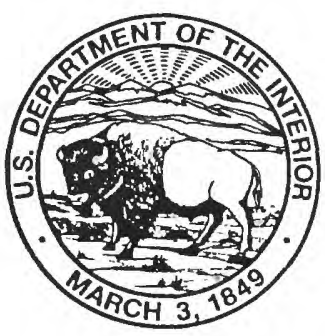

Gordon P. Eaton, Director

The use of firm, trade, and brand names in this report is for identification purposes only and does not constitute endorsement by the U.S. Geological Survey.

For additional information write to:

District Chief

U.S. Geological Survey

677 Ala Moana Blvd., Suite 415

Honolulu, HI 96813
Copies of this report can be purchased from:

U.S. Geological Survey

Branch of Information Services

Box 25286

Denver CO 80225-0286 


\section{CONTENTS}

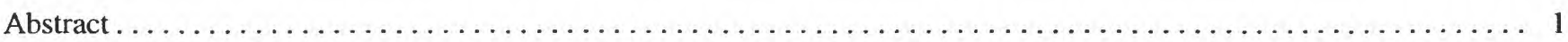

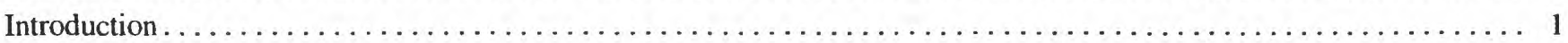

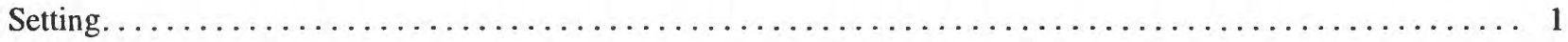

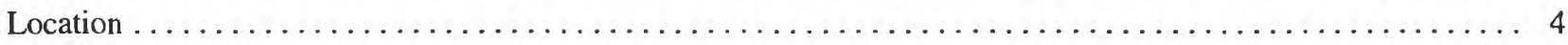

Acknowledgments . . . . . . . . . . . . . . . . . . . . . . . . . . .

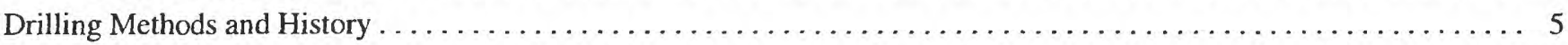

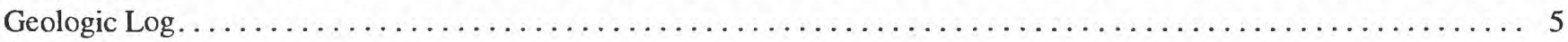

Summary . . . . . . . . . . . . . . . . . . . . . . . . . . . . . . . . .

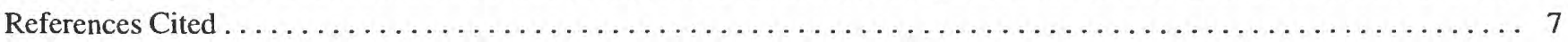

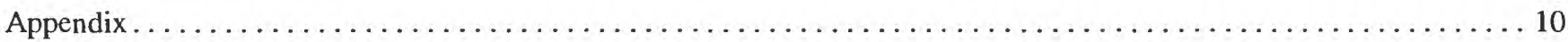

FIGURES

1-2. Maps showing:

1. Location of the South Wailua monitor well (State well 2-0121-01) and existing wells in the Lihue basin, Kauai, Hawaii . . . . . . . . . . . . . . . . . . . . . . . . . . .

2. Geology of the Lihue basin area, Kauai, Hawaii . . . . . . . . . . . . . . . . . . . 3

3-4. Drawings showing:

3. Construction details of the South Wailua monitor well (State well 2-0121-01), Kauai, Hawaii . . . . . . . 6

4. Geologic $\log$ and caliper-arm extension with depth in the South Wailua monitor well (State well 2-0121-01), Kauai, Hawaii. . . . . . . . . . . . . . . . . . . . . .

\section{TABLES}

1. Location, elevation, and State number of the South Wailua monitor well, Kauai, Hawaii . . . . . . . . . . . 4

2. Summary of construction of the South Wailua monitor well (State well 2-0121-01), Kauai, Hawaii.......... 5

CONVERSION FACTORS, ABBREVIATIONS, AND VERTICAL DATUM

\begin{tabular}{rll}
\hline Multiply & By & To obtain \\
\hline inch (in.) & 2.54 & centimeter \\
foot $(\mathrm{ft})$ & 0.3048 & meter \\
cubic foot per minute $\left(\mathrm{ft}^{3} / \mathrm{min}\right)$ & 0.02832 & cubic meter per minute \\
gallon per minute $(\mathrm{gal} / \mathrm{min})$ & 3.785 & liter per minute \\
mile, statute $(\mathrm{mi})$ & 1.609 & kilometer \\
\hline
\end{tabular}

Other Useful Conversions

$1 \mathrm{ft}^{3} / \mathrm{s}=448.8 \mathrm{gal} / \mathrm{min}$

$1 \mathrm{ft}^{3} / \mathrm{s}=0.6463 \mathrm{Mgal} / \mathrm{d}$

\section{Vertical datum}

All elevations in this report are referenced relative to mean sea level.

\section{Abbreviation:}

$\mu \mathrm{S} / \mathrm{cm}$, microsiemens per centimeter at 25 degrees Celsius. 


\title{
Construction and Geologic Log of the South Wailua Monitor Well (State Well 2-0121-01), Lihue, Kauai, Hawaii
}

\author{
By Scot K. Izuka and Stephen B. Gingerich
}

\section{Abstract}

The South Wailua monitor well, located in the Lihue basin near the western slope of Kalepa Ridge, was drilled in 1995 to study the hydrology and geology in an area where no other well information is available. The well was drilled to an elevation of -854 feet from a ground elevation of about 289 feet and penetrated a 1,143-foot section of mafic lava flows (which may include nephelinite, melilitite, basanite, and alkalic basalt, in part highly weathered), alluvial gravel, clay, and a layer of mudstone (possibly weathered ash) with wood fossils. Little water was found during drilling. An aquifer test was attempted but the pump became clogged with mud. A water-level elevation of 13.9 feet was measured before the test.

\section{INTRODUCTION}

The Lihue basin is the center of population, government, and industry for Kauai. Recent population growth in the basin has greatly increased the demand for water in the area. The economic setback caused by Hurricane Iniki in 1993 slowed growth on Kauai and may have kept the water supply from reaching a critical stage; however, an ample water supply is needed for the island's economic recovery. Pre-Iniki studies placed Lihue's supply at the highest priority in Kauai's water plans (Commission on Water Resources Management, 1990).

The South Wailua monitor well (State well 20121-01) is one of six monitor wells drilled in the period from April 1995 to April 1996 by the U.S. Geo- logical Survey (USGS) in cooperation with the County of Kauai Department of Water to study the availability of ground water in the southern Lihue basin (fig. 1). The six monitor wells were sited in areas where no wells had been drilled and no subsurface information was available. Five of the six monitor wells were drilled in the central part of the Lihue basin. The sixth well was drilled in the southern part of the basin. The South Wailua monitor well is about $1 \mathrm{mi}$ from the nearest previously existing wells and provides data for defining the regional ground-water system of the Lihue basin. The Department of Water considers the South Wailua area as a potential site for future ground-water exploration and development.

The objectives of this study were met by analysis of data collected during and after the drilling operation. These data included (1) the driller's description of the drilling history and well-construction details, (2) water levels monitored as the well was deepened, (3) a caliper log of the uncased well boring, and (4) a description of the geology from rock chips (cuttings) brought to the surface during drilling. This report documents the location, drilling history, construction details, and geologic $\log$ of the South Wailua monitor well.

\section{Setting}

The South Wailua monitor well (State well 20121-01) is located in the Lihue basin, a large depression bounded on the west by the high mountains of central Kauai, on the south by Haupu Ridge, and on the north by the Makaleha Mountains (fig. 1). The area has undergone substantial stream erosion, weathering, and faulting followed by rejuvenated, sporadic, scattered volcanism. Two major stratigraphic units are found in the Lihue basin (fig. 2): (1) the Waimea Canyon Basalt 


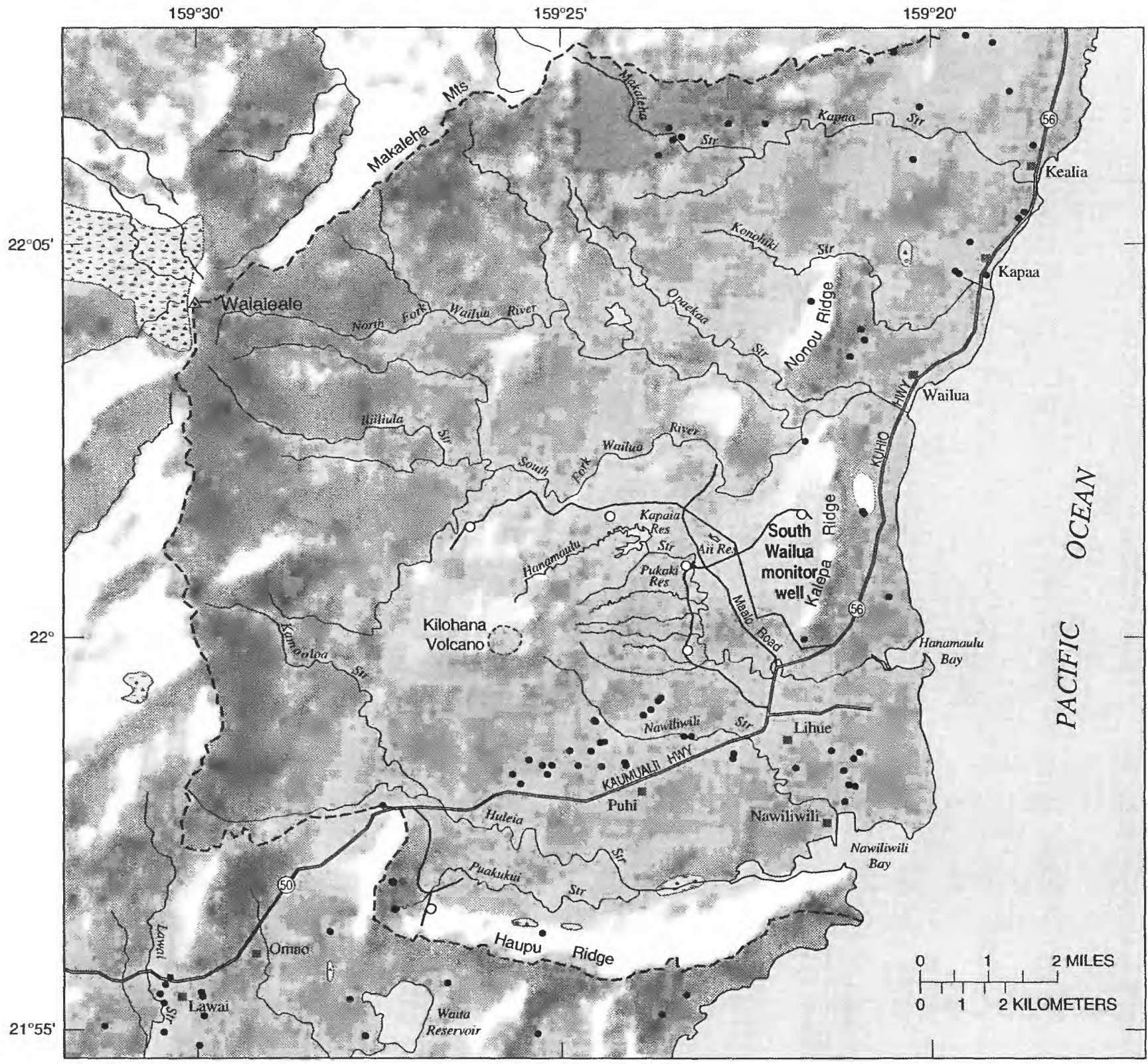

Base modified from U.S. Geological Survey digital data 1.24,000,1983. Albers equal area projection, standard parallels $21^{\circ} 55^{\prime} 40^{\prime \prime}$ and $22^{\circ} 10^{\prime \prime} 20^{\prime \prime}$, central meridian $159^{\circ} 32^{\prime} 30^{\prime \prime}$. Relief from U.S. Geobgical Survey digital elevation models, 1:250,000

\section{EXPLANATION}

$\begin{array}{ll}- & \text { BOUNDARY OF L } \\ - & \text { MONITOR WELL } \\ & \text { EXISTING WELL } \\ & \text { SWAMP } \\ & \text { SPRING }\end{array}$

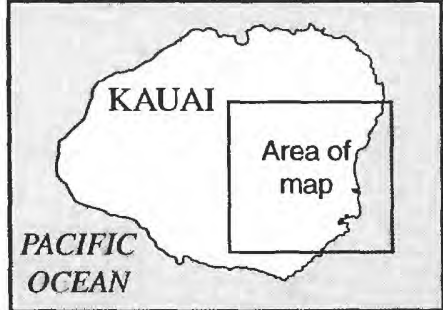

Figure 1. Location of the South Wailua monitor well (State well 2-0121-01) and existing wells in the Lihue basin, Kauai, Hawaii. 


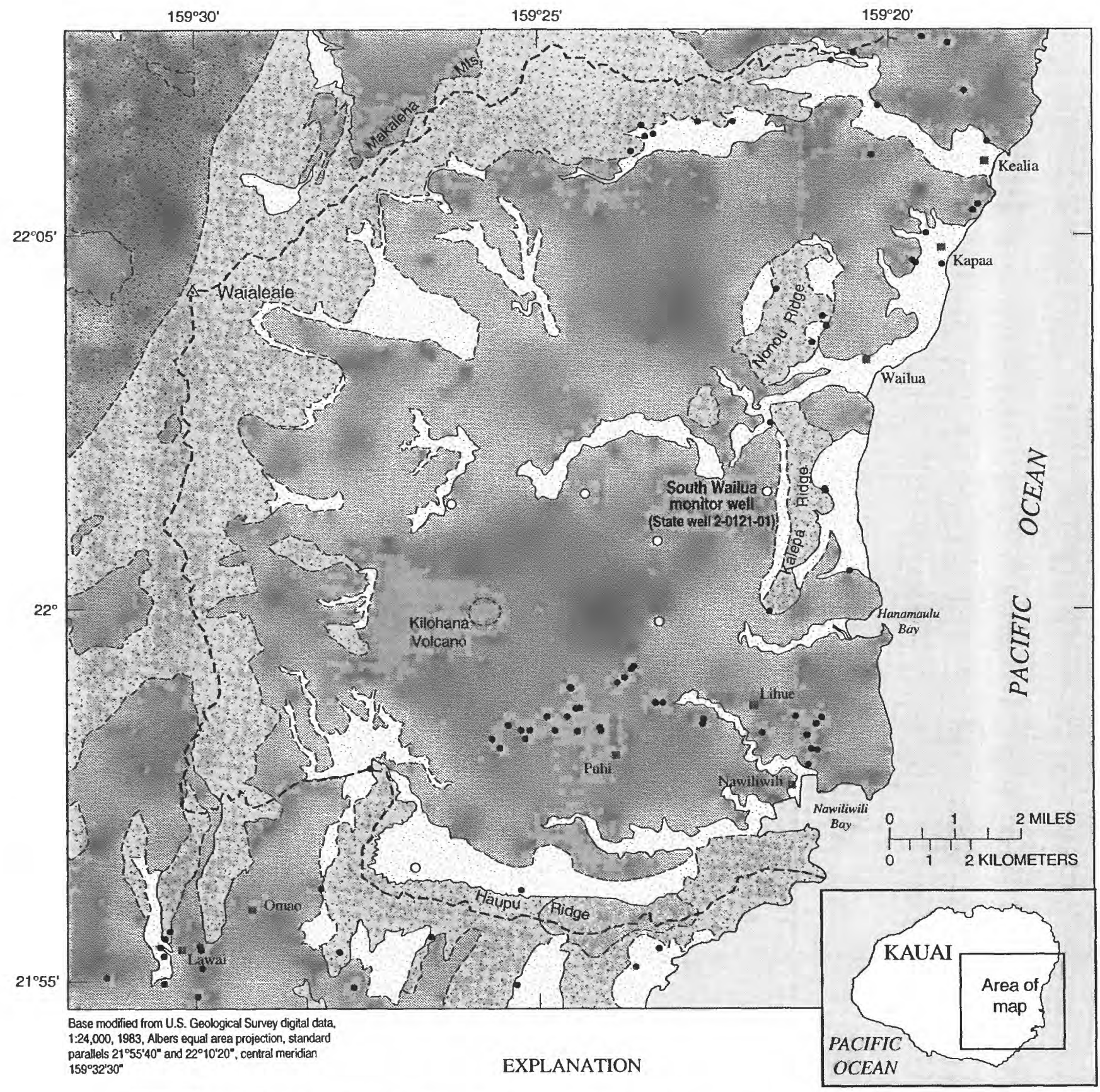
$159^{\circ} 32^{\prime} 30^{\circ}$

SEDIMENTARY DEPOSITS (Holocene, Pleistocene, and Pliocene)

KOLOA VOLCANICS (Pleistocene and Pliocene)

WAIMEA CANYON BASALT (Pliocene and Miocene?)

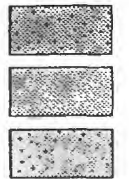

Olokele Member (Pliocene)

Haupu Member (Pliocene)

Napali Member (Pliocene and Miocene?)

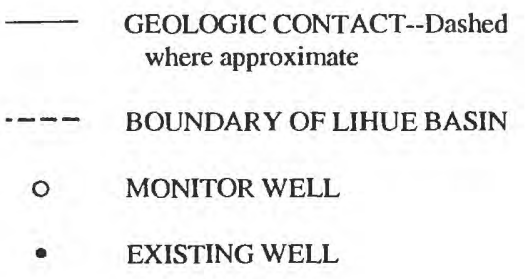

GEOLOGIC CONTACT--Dashed

\section{BOUNDARY OF LIHUE BASIN}

EXISTING WELL

Figure 2. Geology of the Lihue basin area, Kauai, Hawaii (modified from Macdonald and others, 1960). 
of Pliocene and Miocene (?) age which was erupted during the main shield-volcano-building stage of Kauai and forms the bulk of the island, including the mountains surrounding the Lihue basin, and (2) the Koloa Volcanics of Pleistocene and Pliocene age which include the rejuvenated-stage lava flows and sedimentary units that partly cover and fill the floor of the basin (Hinds, 1930; Stearns, 1946; Macdonald and others, 1960). Both the Waimea Canyon Basalt and the Koloa Volcanics have been given formational rank (Langenheim and Clague, 1987).

Kilohana Volcano in the center of the Lihue basin is a prominent edifice of the Koloa Volcanics. Macdonald and others (1960) described the Lihue basin as a subsidiary caldera that formed to the east of a central main caldera of the Kauai shield volcano. Stearns (1946) described the basin as the result of advanced stream erosion and the coalescing of many amphitheater-headed valleys. Numerous subsequent geologic investigations include a gravity survey (Kivroy and others, 1965), petrologic and geochemical analyses (Macdonald, 1968; Feigenson, 1984; Clague and Dalrymple, 1988; Maaloe and others, 1992), and radiometric dating (Clague and Dalrymple, 1988). These studies have advanced the understanding of the geology of Kauai, yet the origin of the Lihue basin remains an enigma.

Ground-water exploration in the Lihue basin has been only moderately successful, owing in part to the basin's complex ground-water hydrology. Most of the ground water in the Lihue basin is developed from wells in the Koloa Volcanics, which cover almost the entire basin floor. The Koloa Volcanics are generally considered to have low to moderate permeabilities (Macdonald and others, 1960), but specific capacities of wells in this unit are highly variable. Water levels during drilling in many of these wells declined with depth in the aquifer, indicating substantial vertical head gradients. At the base of the Koloa Volcanics and resting unconformably on the underlying Waimea Canyon Basalt, are the weathered rocks and sedimentary deposits that formed during the period of erosion between the shield-volcano eruptions and the rejuvenated volcanism. These deposits probably have low permeabilities and may retard the flow of water between the Koloa Volcanics and the Waimea Canyon Basalt.

The Waimea Canyon Basalt in the Lihue basin is represented by the Napali Member, the thick accumulations of thin lava flows that formed on the flank of the Kauai shield volcano. In western Kauai, the Napali
Member is extensive and forms the most permeable aquifers on Kauai, but in the Lihue basin, the Napali Member crops out only in the mountains encircling the basin. It is not certain whether any of the wells drilled thus far in the center of the basin have penetrated through the Koloa Volcanics and into the underlying Napali Member. Therefore, the thickness of the Koloa Volcanics and the hydrologic properties of the underlying Napali Member are unknown.

\section{Location}

The South Wailua monitor well (State well 20121-01) is located in the Lihue basin between sugarcane fields near the western slope of Kalepa Ridge (fig. 1 , table 1). The site is on the western shoulder of a sugar plantation road, about $1.7 \mathrm{mi}$ east of the intersection with Maalo Road. The well was assigned the well number 2-0121-01 by the State of Hawaii Commission on Water Resources Management using the State well numbering system.

Table 1. Location, elevation, and State number of the South Wailua monitor well, Kauai, Hawaii

[Datum is mean sea level]

\begin{tabular}{ll}
\hline Latitude & $22^{\circ} 01^{\prime} 31^{\prime \prime} \mathrm{N}$ \\
Longitude & $159^{\circ} 21^{\prime} 47^{\prime \prime} \mathrm{W}$ \\
Ground elevation at brass plate in concrete pad & $289.22 \mathrm{feet}$ \\
$\begin{array}{l}\text { Measuring-point elevation at top of 4-inch well } \\
\quad \text { casing }\end{array}$ & $290.16 \mathrm{feet}$ \\
Distance and direction from Lihue & 3.2 miles north \\
Distance and direction from nearest shoreline & 1.4 miles west \\
State well number & $2-0121-01$ \\
\hline
\end{tabular}

The area within a $1 \mathrm{mi}$ radius of the well is covered by a network of artificial and natural surface-water bodies. The Wailua River is within 0.8 mi northwest of the well and a swamp lies $0.9 \mathrm{mi}$ to the east on the other side of Kalepa Ridge. The well is located about $1.4 \mathrm{mi}$ inland from the eastern coast of Kauai.

\section{Acknowledgments}

The construction, data collection, and testing of the South Wailua monitor well was made possible with the cooperation and assistance of Mr. Murl Nielsen, Manager and Chief Engineer, and the staff of the County of Kauai Department of Water. We are grateful to Mr. Sam Lee, Hawaii State Department of Land and Natural 
Table 2. Summary of construction of the South Wailua monitor well (State well 2-0121-01), Kauai, Hawaii

[Datum for water-level and bottom-of-hole elevations is mean sea level. Land surface elevation is about $289 \mathrm{ft}$ above mean sea level; $\mathrm{ft}$, feet]

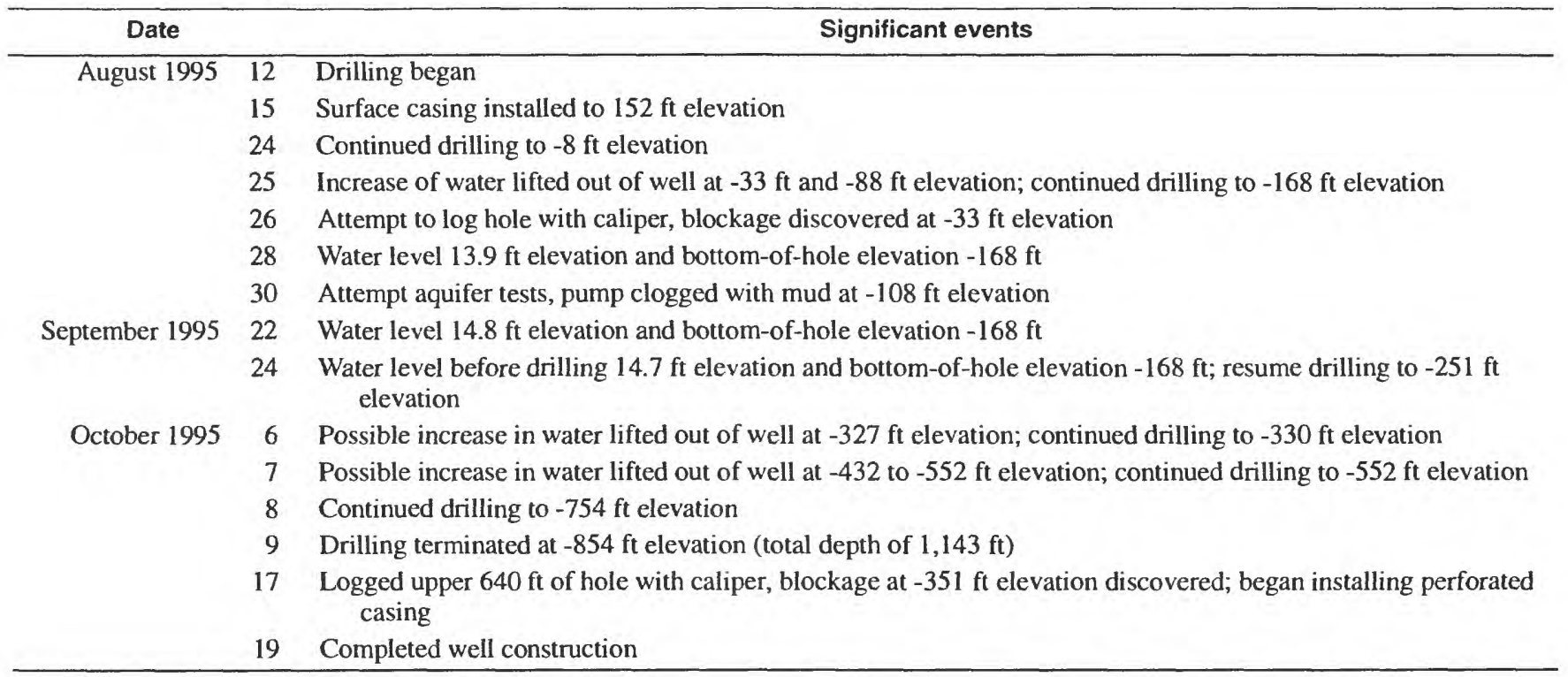

Resources, for helping acquire permission to drill the well on State land and to Mr. Michael Furukawa for permitting the construction of the well on a part of the State land leased by Amfac/JMB Hawaii, Lihue Plantation. Drilling, aquifer-test, and elevation information were drawn extensively from the notes of G. Wayne Heick of the U.S. Geological Survey.

\section{DRILLING METHODS AND HISTORY}

The well was bored by rotary drilling with a 9-7/8in. diameter tungsten-carbide bit from the surface (289 $\mathrm{ft}$ elevation) to an elevation of $-251 \mathrm{ft}$, and an 8-3/4-in. diameter tungsten-carbide bit from $-251 \mathrm{ft}$ to $-854 \mathrm{ft}$. Air and foam were injected down through the hollow drill stem and circulated back up the space between the stem and the well boring to remove water and cuttings from the hole. Greater lifting power was needed as the drilling penetrated deeper below the water table. The depth of drilling was thus limited by the capacity of the air compressor to provide the circulation. Table 2 summarizes the construction history of the well.

The drillers reported wet clay from the surface, but no standing water until they had drilled $15 \mathrm{ft}$ and the bottom of the hole was at $274 \mathrm{ft}$ elevation. The drillers estimated that the amount of water lifted out of the hole by the compressor was at most only about $50 \mathrm{gal} / \mathrm{min}$, which indicates that little water was flowing into the well from the aquifer. The drillers also reported many unconsolidated sediment (especially clay) layers. Drilling was halted temporarily to attempt an aquifer test while the hole bottom was at an elevation of $-168 \mathrm{ft}$. A water-level elevation of $13.9 \mathrm{ft}$ was measured prior to the test. The pump immediately became clogged with mud so the test was halted. Drilling resumed from -168 $\mathrm{ft}$ elevation and was terminated when the bottom of the hole was at an elevation of $-854 \mathrm{ft}(1,143 \mathrm{ft}$ total drilling depth). A caliper tool was run down the hole on October 17,1995 to record the caliper arm extension, an indication of the variation in hole diameter with depth. At $-351 \mathrm{ft}$ elevation a blockage was discovered; casing was installed through the blockage down to an elevation of $-561 \mathrm{ft}$ and the well was completed on October 19 , 1995. The elevation of a brass plate in the concrete pad at the well is $289.22 \mathrm{ft}$ and the elevation of the measuring point at the top of the casing is $290.16 \mathrm{ft}$. Construction details of the finished well are shown in figure 3 . Plans to conduct aquifer tests after the completion of the well were abandoned because of the small amount of water found during drilling and the likelihood that the pump would again become clogged with sediment.

\section{GEOLOGIC LOG}

The geologic log of the South Wailua monitor well was compiled by examination of cuttings brought to the 


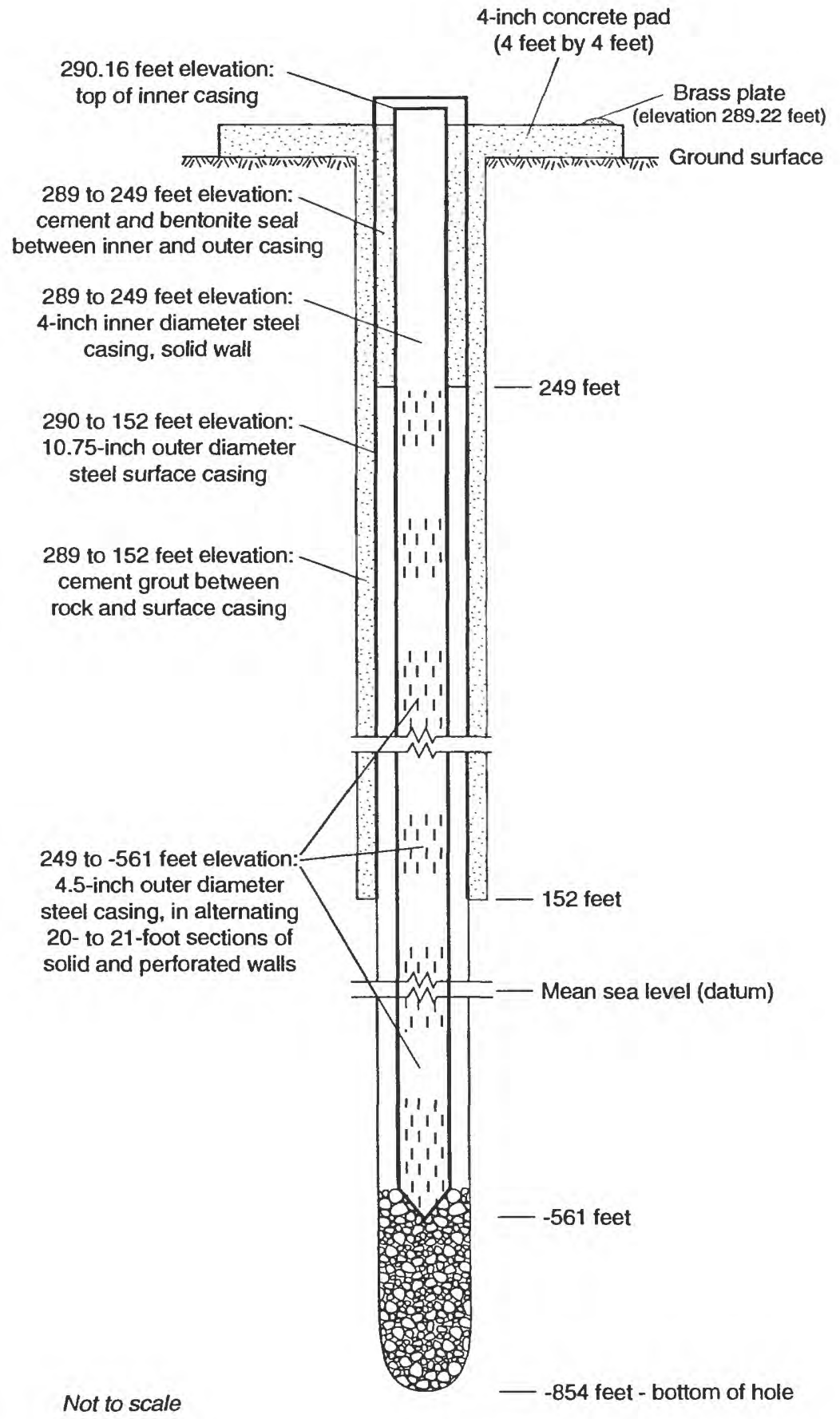

Figure 3. Construction details of the South Wailua monitor well (State well 2-0121-01), Kauai, Hawaii. 
surface by the air and foam circulated through the well bore. Samples were collected at 5 -ft depth intervals and air dried before being examined macroscopically. The complete lithologic descriptions appear in appendix 1; the geologic log is shown in figure 4 .

The South Wailua monitor well penetrated a 1,143-ft section of mafic lava flows and alluvium ("mafic rock" in this report includes nephelinite, melilitite, basanite, and alkalic basalt, all of which are dark, fine-grained, igneous rocks but have specific compositions that are not distinguishable in hand specimen). The uppermost part of the section consists of a $30-\mathrm{ft}$ layer of moist, sticky clay. Underlying the clay is a 165 $\mathrm{ft}$-thick section of lava flows (in part highly weathered), alluvium, and clay. This section is underlain by $35-\mathrm{ft}$ layer of mudstone (possibly weathered ash) with wood fossils. Underlying the fossiliferous mudstone is a 395 ft-thick section composed mostly of dense, aphyric mafic rock but also containing some sparsely vesicular mafic rock, amygdaloidal mafic rock, ash, clay, and alluvial gravel. The remaining $525 \mathrm{ft}$ of rock penetrated by the well is composed almost entirely of alluvial gravel except for a few, thin, intercalated lava flows.

The caliper log of the South Wailua monitor well (fig. 4) shows intervals where the hole deviates from the drill-bit diameter. Rock layers that are unconsolidated or thin tend to crumble and cave to produce enlargements in the well boring. In contrast, rocks that are hard, massive, and thick tend to hold the shape of the boring, and thus give a smoother, unvarying log. Below the surface casing (surface casing shows as the smooth upper $130 \mathrm{ft}$ of the caliper log), the log shows an enlargement between -21 and $-31 \mathrm{ft}$ elevation and another between $-331 \mathrm{ft}$ and $-341 \mathrm{ft}$ elevation that correspond approximately with some of the unconsolidated sedimentary layers shown in the geologic log. The well boring is slightly enlarged from an elevation of about $-361 \mathrm{ft}$ down to the bottom of the hole, which corresponds to the thick layers of unconsolidated sediments shown at the base of the geologic log.

\section{SUMMARY}

The South Wailua monitor well (State well 20121-01) is located in the Lihue basin between sugarcane fields near the western slope of Kalepa Ridge. The well was constructed during the period from August 12 to October 19, 1995 to study the hydrology and geology in an area where no other well information is available. The ground elevation at the well is 289 feet and the well is 1,143 feet deep (bottom is at -854 feet elevation) and has a boring diameter of 9 to 10 inches. Flush-jointed 4inch (outer diameter) steel casing, with perforated sections between the water table and the bottom, was installed in the hole.

The amount of water lifted out of the hole during drilling was at most only about 50 gallons per minute, which indicates that little water was flowing into the well from the aquifer. An aquifer test was attempted while the hole bottom was at an elevation of -168 feet. The pump immediately became clogged with mud so the test was halted. A water-level elevation of 13.9 feet was measured prior to the test. At -351 feet elevation a blockage was discovered; casing was installed through the blockage down to an elevation of -561 feet.

The South Wailua monitor well penetrated a 1,143-foot section of mafic lava flows (in part highly weathered), alluvial gravel, clay, and a layer of mudstone (possibly weathered ash) with wood fossils.

\section{REFERENCES CITED}

Clague, D.A., and Dalrymple, G.B., 1988, Age and petrology of alkalic post-shield and rejuvenated stage lava from Kauai, Hawaii: Contributions to Mineralogy and Petrology, v. 99, p. 202-218.

Commission on Water Resource Management, 1990, State water resources protection plan: prepared by George A.L. Yuen and Associates for the Hawaii State Department of Land and Natural Resources, variously paginated.

Feigenson, M.D., 1984, Geochemistry of Kauai volcanics and a mixing model for the origin of Hawaiian alkali basalts: Contributions to Mineralogy and Petrology, v. 87, p. $109-119$.

Hinds, N., 1930, The geology of Kauai and Niihau: Bernice Pauahi Bishop Museum Bulletin 71, 103 p.

Kivroy, H.L., Baker, M., and Moe, E.E., 1965, A reconnaissance gravity survey of the island of Kauai: Pacific Science, v. 19, p. 354-358.

Langenheim, V.A.M., and Clague, D.A., 1987, Stratigraphic framework of volcanic rocks of the Hawaiian Islands, in Decker, R.W., and others, eds., Volcanism in Hawaii: U.S. Geological Survey Professional Paper 1350, v. 1, p. 55-84. 
Maaloe, S., James, S., and Smedley, D., 1992, The Koloa volcanic suite of Kauai, Hawaii: Journal of Petrology, part 4, v. 33, p. 761-748.

Macdonald, G.A., 1968, Composition and origin of Hawaiian lavas: Geological Society of America Memoirs, v. 116, p. $477-522$.

Macdonald, G.A., Davis, D.A., and Cox, D.C., 1960, Geology and ground-water resources of the island of Kauai, Hawaii: Hawaii Division of Hydrography Bulletin 13, $212 \mathrm{p}$.

Stearns, H.T., 1946, Geology of the Hawaiian Islands: Hawaii Division of Hydrography Bulletin 8, 112 p. 


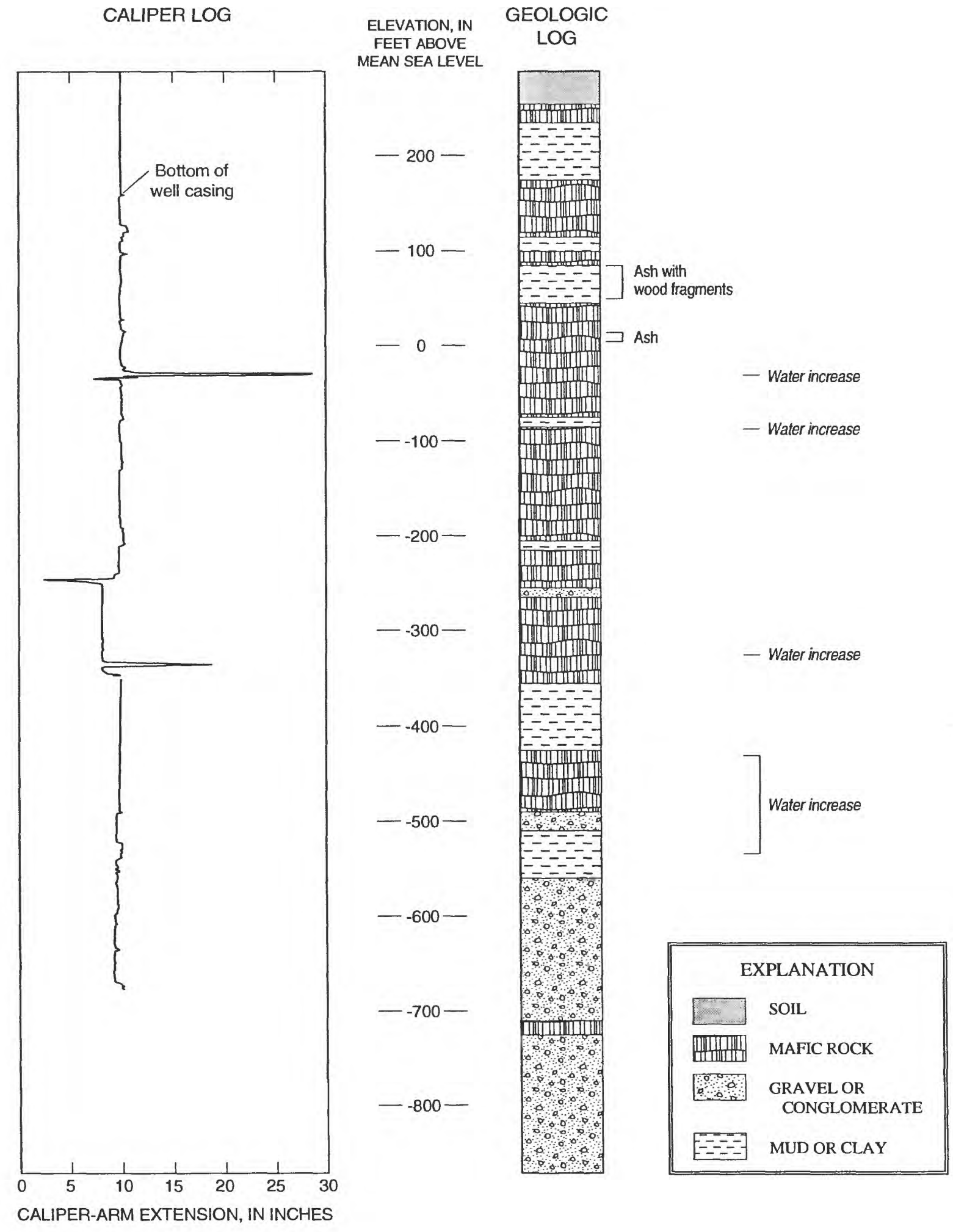

Figure 4. Geologic log and caliper-arm extension with depth in the South Wailua monitor well (State well 2-0121-01), Kauai, Hawaii. 
Appendix 1. Lithologic descriptions of drill cuttings from the South Wailua monitor well (State well 2-0121-01), Kauai, Hawaii [Datum is mean sea level; depth measured from about 289 feet above sea level]

\begin{tabular}{|c|c|c|c|c|c|c|}
\hline \multicolumn{3}{|c|}{$\begin{array}{c}\text { Elevation } \\
\text { (feet) }\end{array}$} & \multicolumn{3}{|c|}{$\begin{array}{l}\text { Depth } \\
\text { (feet) }\end{array}$} & \multirow[t]{2}{*}{ Sample description ${ }^{1}$} \\
\hline 289 & to & 284 & 0 & to & 5 & \\
\hline 284 & to & 279 & 5 & to & 10 & red-brown, sticky clay \\
\hline 274 & to & 269 & 10 & to & 20 & red-brown, sticky clay \\
\hline 269 & to & 264 & 20 & to & 25 & red-brown, sticky clay \\
\hline 264 & to & 259 & 25 & to & 30 & no sample \\
\hline 254 & to & 249 & 35 & to & 40 & dark-gray, vesicular mafic clinker \\
\hline 249 & to & 244 & 40 & to & 45 & dark-gray, vesicular mafic clinker \\
\hline 244 & to & 239 & 45 & to & 50 & dark-gray, vesicular mafic clinker \\
\hline 239 & to & 234 & 50 & to & 55 & dark-gray, dense, aphyric mafic rock \\
\hline 234 & to & 229 & 55 & to & 60 & red-brown, sticky clay \\
\hline 229 & to & 224 & 60 & to & 65 & red sticky clay, no gravel \\
\hline 209 & to & 204 & 80 & to & 85 & brown, sandy, gravelly mud \\
\hline 204 & to & 199 & 85 & to & 90 & brown, sandy, gravelly mud \\
\hline 199 & to & 194 & 90 & to & 95 & light-brown, sandy clay with flecks of white minerals \\
\hline 194 & to & 189 & 95 & to & 100 & light-brown, sandy clay with flecks of white minerals \\
\hline 189 & to & 184 & 100 & to & 105 & light-brown, sandy clay with flecks of white minerals \\
\hline 184 & to & 179 & 105 & to & 110 & light-brown, sandy clay with flecks of white minerals \\
\hline 179 & to & 174 & 110 & to & 115 & light-brown, sandy clay with flecks of white minerals \\
\hline 174 & to & 169 & 115 & to & 120 & purplish-gray, weathered, vesicular mafic rock with white clay \\
\hline 169 & to & 164 & 120 & to & 125 & purplish-gray, weathered, vesicular mafic rock with white clay \\
\hline 164 & to & 159 & 125 & to & 130 & purplish-gray, slightly weathered, vesicular mafic rock \\
\hline 159 & to & 154 & 130 & to & 135 & purplish-gray, slightly weathered, vesicular mafic rock \\
\hline 114 & to & 109 & 175 & to & 180 & red clay with some gravel and deeply weathered mafic rock clasts \\
\hline 109 & to & 104 & 180 & to & 185 & red clay with some gravel and deeply weathered mafic rock clasts \\
\hline 104 & to & 99 & 185 & to & 190 & brown, weathered sand with medium gray dense mafic rock \\
\hline 99 & to & 94 & 190 & to & 195 & dark-gray, dense mafic rock with olivine phenocrysts \\
\hline 94 & to & 89 & 195 & to & 200 & dark-gray, dense mafic rock with olivine phenocrysts \\
\hline 89 & to & 84 & 200 & to & 205 & dark-gray, dense mafic rock with olivine phenocrysts \\
\hline 84 & to & 79 & 205 & to & 210 & olive, consolidated mudstone with some wood fragments \\
\hline 79 & to & 74 & 210 & to & 215 & olive, consolidated mudstone with some wood fragments \\
\hline 74 & to & 69 & 215 & to & 220 & olive, consolidated mudstone with some wood fragments \\
\hline 69 & to & 64 & 220 & to & 225 & olive, consolidated mudstone with some wood fragments \\
\hline 64 & to & 59 & 225 & to & 230 & olive, consolidated mudstone with some wood fragments \\
\hline 59 & to & 54 & 230 & to & 235 & olive, consolidated mudstone with some wood fragments \\
\hline 54 & to & 49 & 235 & to & 240 & olive, consolidated mudstone with some wood fragments \\
\hline 49 & to & 44 & 240 & to & 245 & weathered mafic rock with olive mud \\
\hline 44 & to & 39 & 245 & to & 250 & weathered mafic rock with olive mud \\
\hline 39 & to & 34 & 250 & to & 255 & gray, unweathered mafic rock \\
\hline 34 & to & 29 & 255 & to & 260 & brownish-gray, slightly weathered, sparsely vesicular mafic rock \\
\hline 29 & to & 24 & 260 & to & 265 & brownish-gray, slightly weathered, sparsely vesicular mafic rock \\
\hline
\end{tabular}


Appendix 1. Lithologic descriptions of drill cuttings from the South Wailua monitor well (State well 2-0121-01), Kauai, Hawaii --Continued

[Datum is mean sea level; depth measured from about 289 feet above sea level]

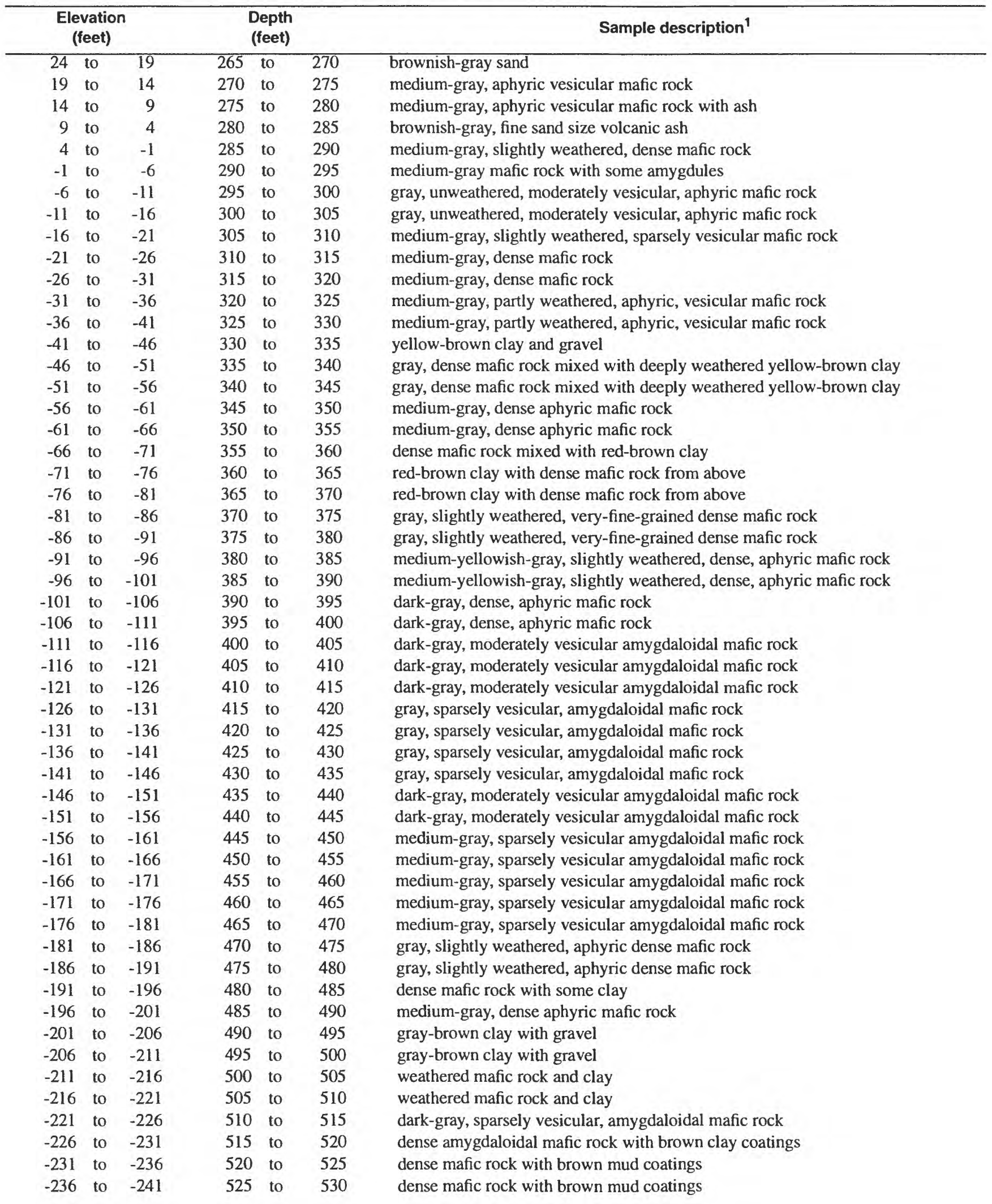


Appendix 1. Lithologic descriptions of drill cuttings from the South Wailua monitor well (State well 2-0121-01), Kauai, Hawaii --Continued

[Datum is mean sea level; depth measured from about 289 feet above sea level]

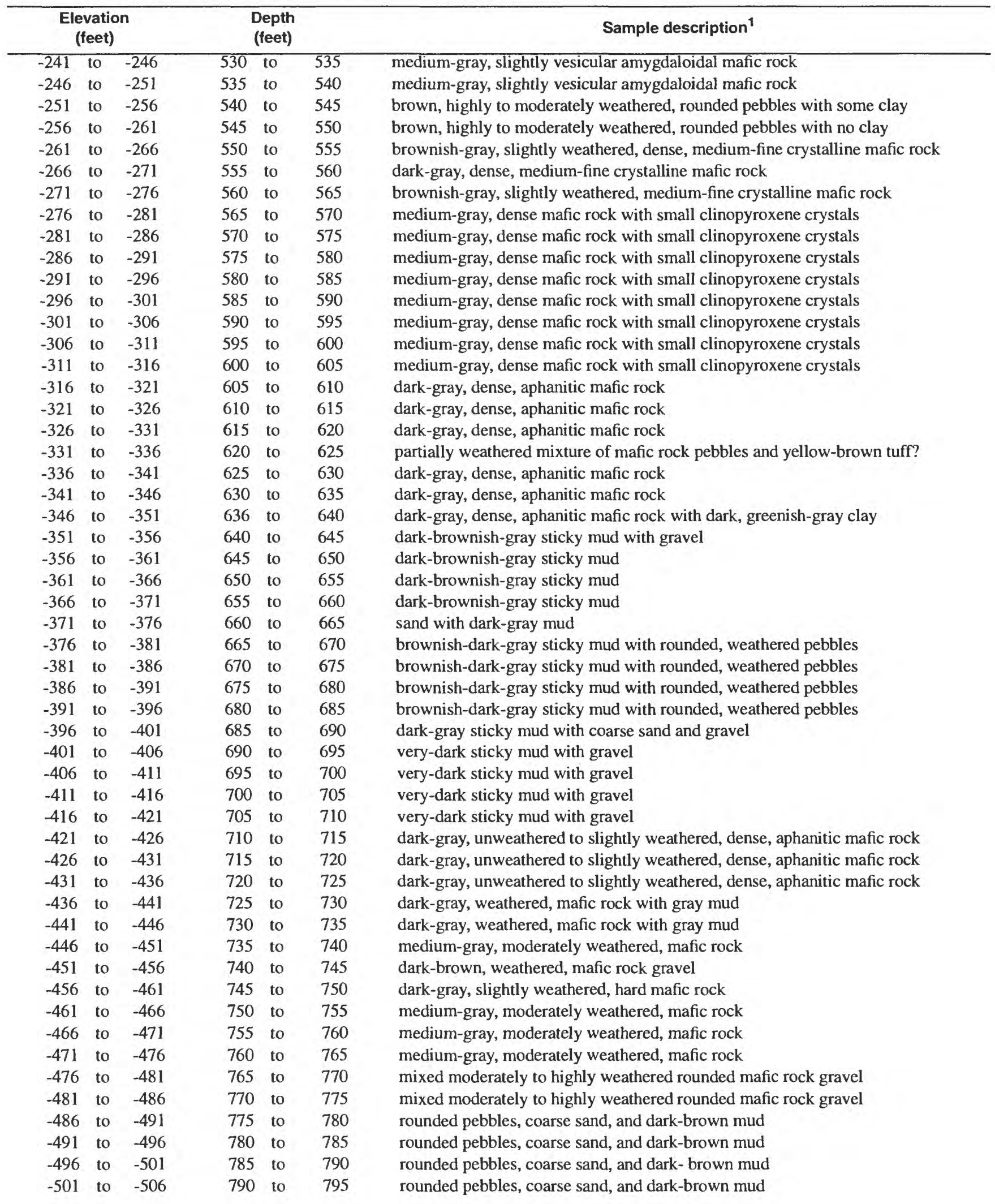


Appendix 1. Lithologic descriptions of drill cuttings from the South Wailua monitor well (State well 2-0121-01), Kauai, Hawaii --Continued

[Datum is mean sea level; depth measured from about 289 feet above sea level]

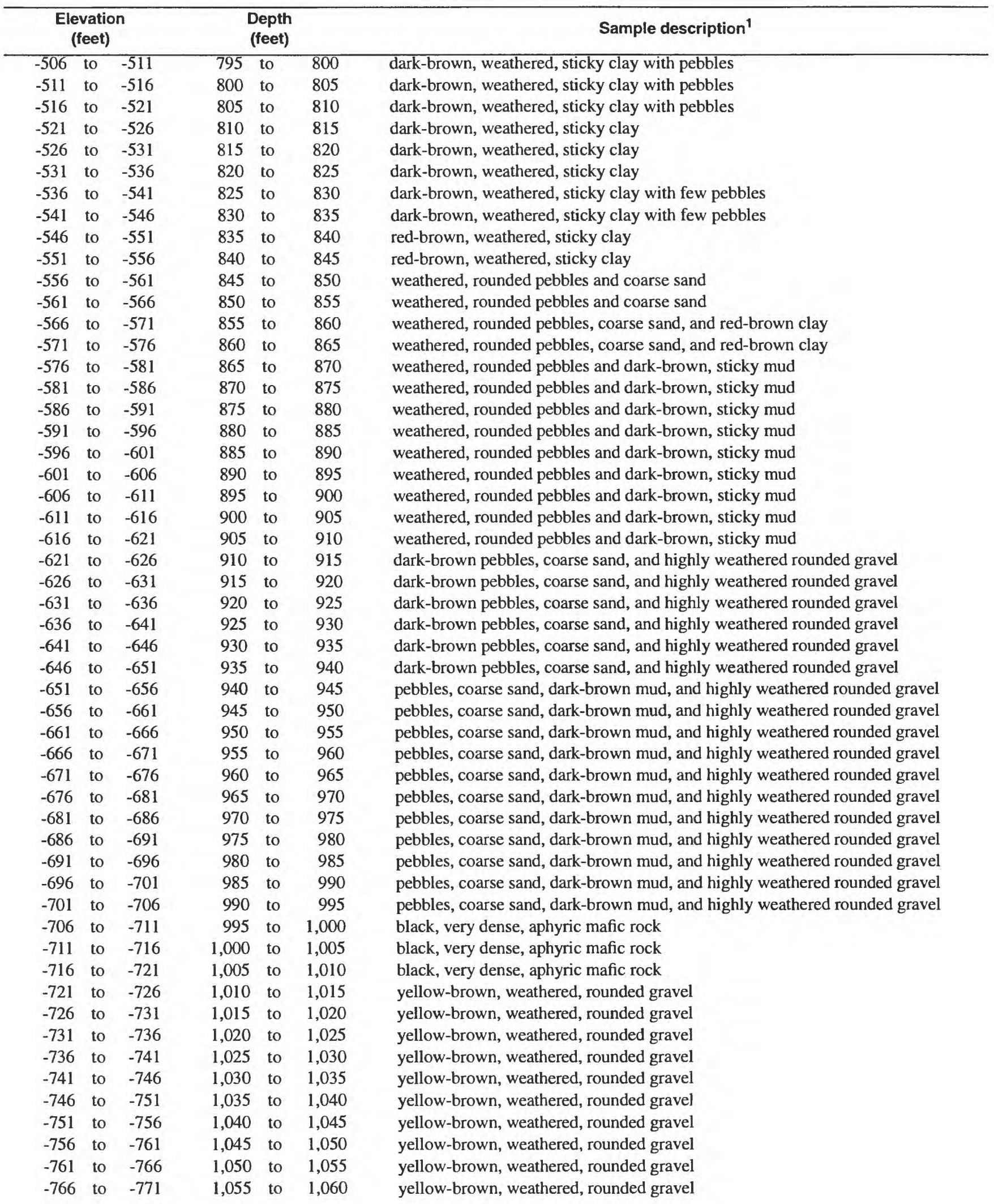


Appendix 1. Lithologic descriptions of drill cuttings from the South Wailua monitor well (State well 2-0121-01), Kauai, Hawaii --Continued

[Datum is mean sea level; depth measured from about 289 feet above sea level]

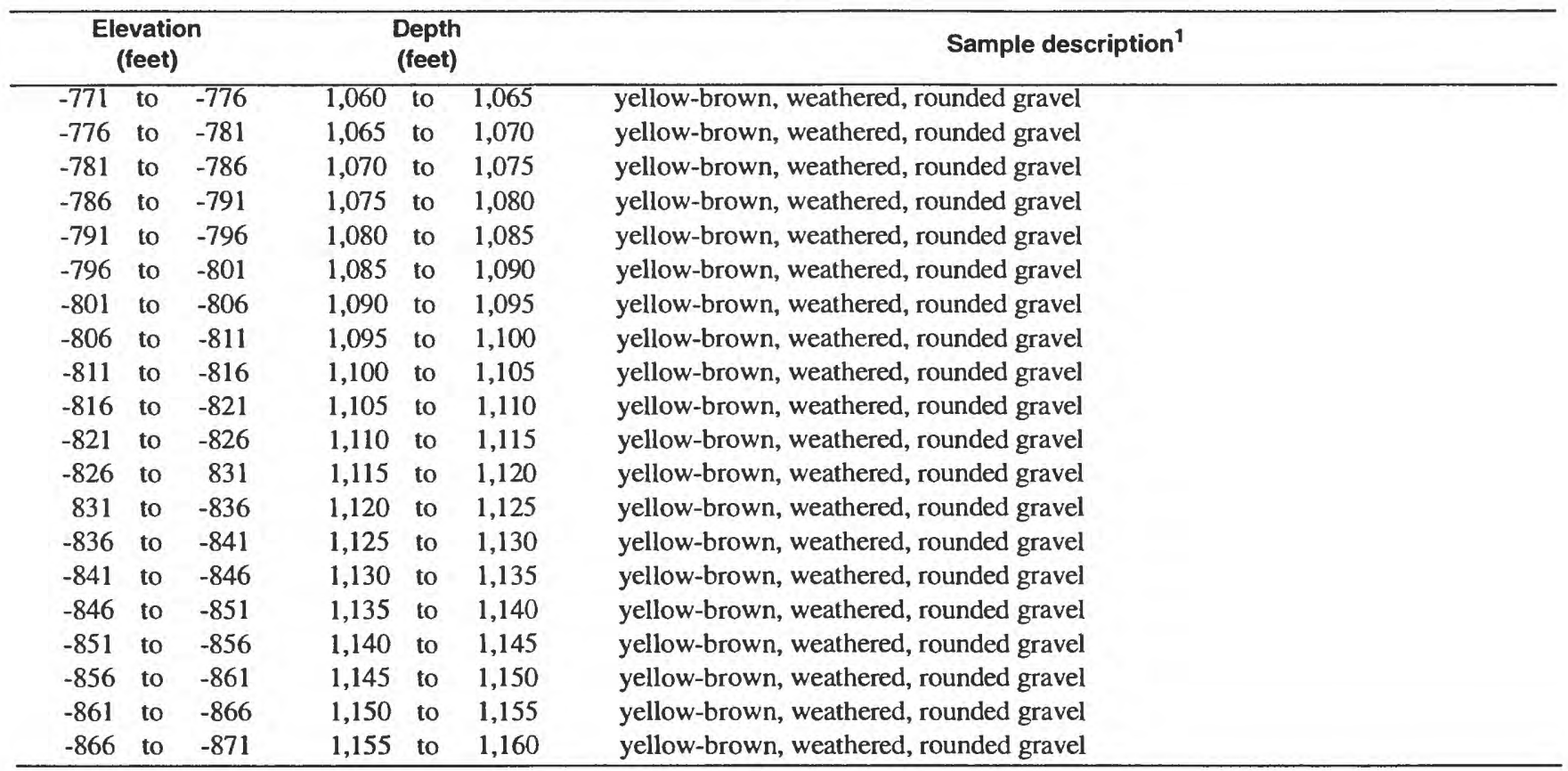

